\title{
The spatial pattern of forest cover changes in Lithuania during the second half of the twentieth century
}

\author{
Daiva Jukneliené, \\ Gintautas Mozgeris \\ Aleksandras Stulginskis University, \\ Studentu St. 11, \\ LT-53361 Akademija, \\ Kaunas Distr., Lithuania \\ E-mail: daiva.jukneliene@asu.lt; \\ gintautas.mozgeris@asu.lt
}

\begin{abstract}
The trends of forest cover change in Lithuanian municipalities are introduced in the current paper. Two sources of information on the forest cover in 1950s and today (2013) were used in this study: (i) a geographic forest cover database developed using historical orthophotomaps based on aerial photography, which was carried out in the period just after the World War II, and (ii) the information originating from the State Forest Cadaster and referring to the year 2013. These two layers were compared using GIS overlay techniques. The data was made available for the analyses aggregated up to the municipality level. The Global Moran's I statistic and Anselin Local Moran's I were used to identify global and local patterns in the distribution of forest cover characteristics in Lithuanian municipalities, respectively. The main finding of this study was that the proportion of the forest cover in 1950 was $26.5 \%$, i. e. notably differing from the official statistics $-19.7 \%$. The proportion of the forest cover increased in all municipalities during the period 1950-2013. The largest increase in forest cover proportion was in the areas less suitable for agriculture. The relatively largest areas of new forests were identified in the south-eastern part of Lithuania, the deforestation was relatively slowest around less forested municipalities, while the afforestation was relatively slowest around the agricultural Pakruojis municipality. Deforestation was most commonly associated with the forest transformation into agricultural land, less often into scrublands or waters.
\end{abstract}

Key words: forest cover changes, forest cover proportion, afforestation, deforestation, spatial statistics, Moran's I

\section{INTRODUCTION}

There are practically no documented facts on the forest cover in Lithuania before the middle of 18th century, except a rough description by G. Valavičius in 1559 of some wood lots used for game management. More reliable information on total forest covers becomes available only in the second half of 18th century as an outcome of special mapping projects and the general land delineation project started in 1766 (Pauliukevičius, Kenstavičius, 1995). P. Matulionis (1930) suggested forests could cover around 56\% of the Lithuanian territory a millennium ago, with the tendency to decrease significantly over the ages: $54 \%$ in 1200 , $45 \%$ in $1400,44 \%$ in $1600,37 \%$ in 1800 and $24 \%$ in 1900 . The forest cover decrease was associated with the population increase in Lithuania, which was around $6-8$ per $1 \mathrm{~km}^{2}$ in the 10th century, 15 in the 13th century, 22 in the 17th century and currently it is 47 .

Systematic and scientifically sound information on Lithuanian forests became available only in the beginning of 20th century. The official forestry statistics from 1937 identified the forest cover in Lithuania to be $16.7 \%$, excluding the Vilnius region. A. Brukas (1987) estimated that the forest cover throughout the whole current Lithuanian 
territory could amount to 1423 thousand ha, yielding $21.8 \%$. The official forest statistics identify the forest cover changes since the WWII as follows: $1948-19.7 \%, 1956-22.6 \%, 1961-23.9 \%$, 1966 - 24.6\%, 1973 - 26.4\%, 1978 - 27.6\%, $1983-27.9 \%, 1988$ - 27.9\%, 1993 - 28.5\% (Lietuvos miškų..., 2012a). The forest area increase during 1948-1969 is, first of all, explained by the processes of land transfer to the State Forest Fund, large scale afforestation projects as well as natural transformation of other land covers into the forest (Kenstavičius, Brukas, 2003). Such processes got more stable after permanent fields of improved agricultural land were established. After the restoration of Lithuanian Independence in 1990 and during the period of the land reform, the forest area started rapidly to increase due to extensive farming and economic stimulation measures that were applied. There are around 2000 ha of new forests established on non-forest areas annually (Lietuvos miškų..., 2012a). Additionally, around 5 000-6 000 ha of other land cover types naturally get transformed into the forest each year, too (Mizaraite et al., 2010).

However, even if there are sources on the dynamic of forest cover in Lithuania, they are quite difficult to compare. Forest inventories and forest accounting were usually based on somewhat different methods, forest definition as such, territory under focus, especially as it regards forest cover statistics going back to the middle of XX century (Kenstavičius, Brukas, 2003). Forest resource statistics are based on the information originating from stand records with limited information on spatial allocation of forest. Some forests were not accounted at all. For example, the GIS database of Lithuanian forest resources at a scale of 1:150 000 revealed that the actual forest cover in 1990s exceeded the officially declared area by 150000 ha (Kasperavicius et al., 2000). Thus, it is rather difficult to rely on historical records, especially if aiming to study the spatial patterns of forest cover dynamics and relate them with social, economic, political, demographic and other factors. Historical remote sensing data is a powerful solution to travel in the time and to get information on the dynamics of forest cover, reducing the potential bias of conventional sources.

The forest cover database representing Lithuanian forest in 1950s, developed within the frames of the project "Assessment of Forest Changes in Lithuania during 1990-2011", financed by the Ministry of Environment (Lietuvos miškų..., 2012a) has a great potential to discuss in details the forest cover change statistics in Lithuania during the 2nd half of XX century, assess the spatial pattern of changes and relate them with factors potentially influencing the land cover and land use dynamics. Such information is expected to question the official Lithuanian forestry statistics and beliefs of forestry professionals on the afforestation trends during the period after WWII.

The aim of the current paper is to discuss the changes of the forest cover in Lithuania after the WWII. We compare two GIS databases representing the forest cover at a nominal scale of 1:10 000 and referring to two dates - 1950 and 2013. Previous studies on the forest cover dynamics in Lithuania were based on manipulation of aggregated statistics for certain regions of interest. Introduction of geographic information systems (GIS) provides researchers with more powerful tools to disclose the development of phenomena under focus (Longley et al., 2005a; Longley et al., 2005b). In Lithuania, there are very few attempts to use GIS as a tool in the forest pattern analysis. For example, Kucas et al. (2011) applied a multi-scale analysis of forest fragmentation in Lithuania to demonstrate the technique as such. Lazdinis et al. (2005) suggested an alternative - the average shortest distance to the closest forest - to forest cover percentage, better describing the spatial distribution of forested habitats for birds. Here, methods of spatial statistics are used to disclose the global and local patterns of occurred changes. The focus is on the forest cover dynamics aggregated up to the level of Lithuanian municipalities.

\section{MATERIALS AND METHODS}

Two GIS data sources were used to represent the forest cover:

1. The Forest Compartment GIS Database from the State Forest Cadastre, available from the State Forest Service, representing the forest status on Jan 1, 2013, originates from stand-wise forest inventories and is developed at a nominal mapping scale of 1:10 000. Borders of forest compartments in spatially contiguous forest tracts were eliminated to have a single feature representing the forest. 
2. The GIS Database representing the forest cover in 1950s at a nominal scale of 1:10 000 . This database was developed using historical orthophotomaps based on aerial photography carried out in the period just after the World War II. The orthophotomaps were scanned and georeferenced to the Lithuanian Map System. The forest cover was digitized using the manual on-screen digitalization technique and stored in a GIS format. The database was developed within the frames of the project "Assessment of Forest Land Cover Changes in Lithuania during the Period 1990-2011", ordered by the State Forest Service (Lietuvos miškų..., 2012a).

There were also data available from the Land Information System (LIS) - the Land Parcel Block Database (www.geoportal.lt) and borders of municipalities (www.eurogeographics.org) used for the study.

Polygon feature classes representing the forest in 1950 and 2013, the land parcel blocks and the borders of municipalities were overlaid using the conventional GIS Identity Function with the borders of municipalities as the input feature class and all other layers as the identity feature classes. Then, simple database queries and area summarizing were applied to determine for each municipality the following characteristics related to forest cover change:

- Area of forest in 1950 and 2013 by municipalities.

- Forest cover changes during the investigated period by municipalities, i. e. area covered by forest in 1950 and 2013, forest in 1950, but nonforest in 2013 and non-forest in 1950, but forest in 2013.

- For the areas which lost the forest cover since 1950, the current land cover type was identified using the LIS data. This information is available for the analyses summarized by municipalities, too.

All the above mentioned information was stored in a single database. Choropleth maps were developed to illustrate the characteristics of forest cover dynamics by municipalities. The Global Moran's I statistic was calculated to assess the level of spatial autocorrelation of characteristics being analysed. The Spatial Autocorrelation (Moran's I) tool available in the ArcGIS software with conceptualization of spatial relationships based on the "Edge-corners" contiguity was applied (Getis, Ord, 1992; Mitchel, 2005). The Cluster and Outlier Analysis (Anselin Local Moran's I - Anselin, 1995; Mitchel, 2005) was used to identify hot spots, cold spots, and spatial outliers in the distribution of forest cover characteristics in Lithuanian municipalities. The ArcGIS software was used to perform all data processing, analysis and representations.

\section{RESULTS AND DISCUSSIONS}

The total area of forest cover, as it was identified in the Forest Cover GIS Database 1950, was 1733 thousand ha, resulting in the forest area proportion of $26.5 \%$. This figure exceeds the official statistics and assumptions by forest management (Lietuvos mišku...., 2012a). For example, the forest area deducted by Kenstavičius and Brukas (2003) could be around $22.3 \%$ just after the World War II. Accepting some potential differences in the forest cover definition used to account the forest officially and in the current study, we may consider our evaluation as an indication of true forest cover at the beginning of the investigation period. The official statistics suffered from the lack of data (lost, not available, etc.), thus it potentially involved omission errors. On the other hand, our figure may contain some commission error or overestimation due to considering non-forest areas with woody vegetation as the forest. However, the estimation for the 1950s was based on the same methodological approach as the one used to get the estimates for the year 2013 - i. e. the same forest definition, interpretation of orthophotos using similar techniques, utilization of data within the frames of the same project (Lietuvos miškų..., 2012a). The total forest area increased by $21 \%$ to reach 2195 thousand ha nowadays. The proportion of the forest cover area increased in all municipalities. The changes of the forest area proportion by municipalities exhibit a spatial pattern (Fig. 1) the pattern of the forest cover dynamics is statistically significantly clustered - the Global Moran's $I$ Statistic equals $0.184(Z=2.689, p=0.007)$. The global trend is quite well seen - the relatively largest increase in the forest cover proportion was in the areas less suitable for agriculture, especially in hilly landscapes of Žemaitija and Aukštaitija. The pattern of the forest cover proportion in municipalities was not significantly different than 


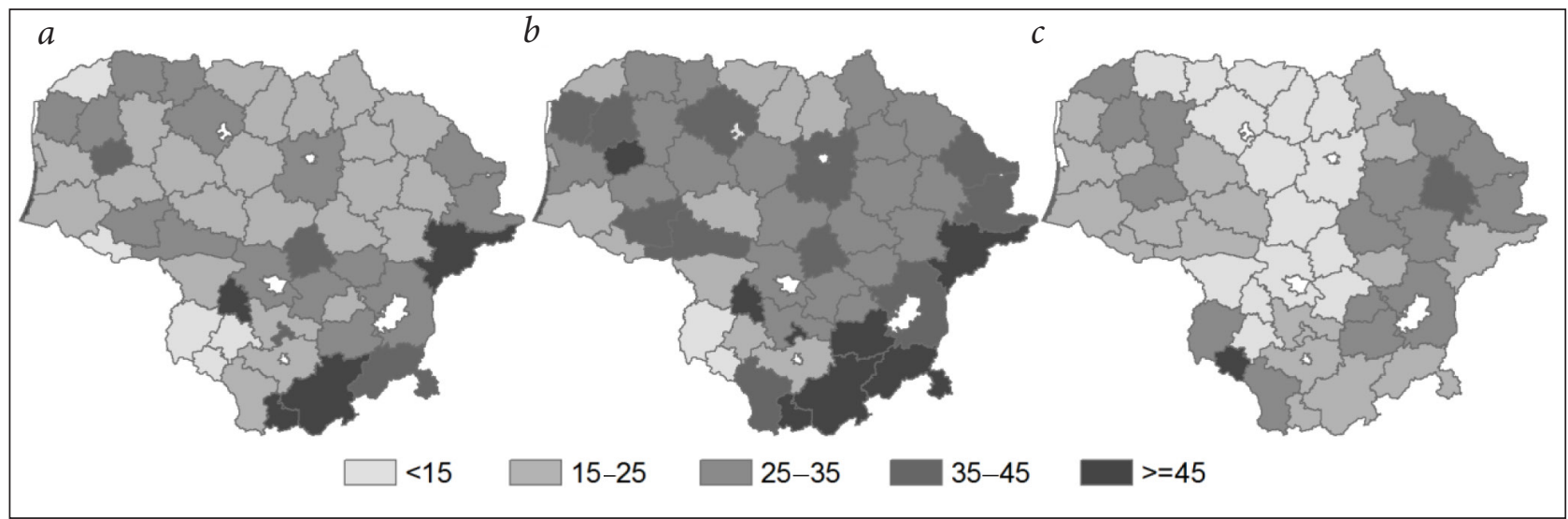

Fig. 1. Forest cover and the forest cover changes in Lithuanian municipalities during the period 1950-2013: a - forest cover proportion in 1950, \%, b - forest cover proportion in 2013, \%, c - increase of forest cover proportion, in per cents, during the period 1950-2013

the random nor in $1950(I=0.004, Z=0.275$, $p=0.784)$ neither in $2013(I=0.039, Z=0.709$, $p=0.478)$.

Three municipalities in southern Lithuania - Druskininkų, Varènos and Šalčininkų - were identified as statistically significant High-High Clusters both in 1950 and 2013, i. e. indicating the features having a high value and being surrounded by features with high values (Fig. 2). The area currently belonging to the Kalvarijos municipality remained the whole period Low-Low cluster, i. e. it had a low forest cover proportion and was surrounded by other municipalities with low forest area proportions. Kazlų Rūda could be considered as a spatial outlier - it was surrounded by municipalities with low forest area proportions while having a high value itself. Hot spots, indicating the clusters with the fastest rate of for- est proportion increase, were Kalvarija and Utena municipalities. The relatively slowest increase in the forest cover area proportion was around Joniškis, Pakruojis, Kèdainiai and Kaunas municipalities, i. e. in the central part of the country with increased focus on agriculture, significant areas of land reclamation.

Even the forest area in Lithuanian municipalities tended to increase, there were several trends in the forest cover changes - the available forest was converted into other land cover types (11.3\%) and other land cover types were turning into the forest (37\%). A majority of forests remained the forests in 2013 (on average $88.7 \%$ ). Spatial patterns of new forest areas and the deforestation in general tend to follow the trends observed analysing the total change of the forest area in the municipalities (Fig. 3). Municipalities with relatively more favourable

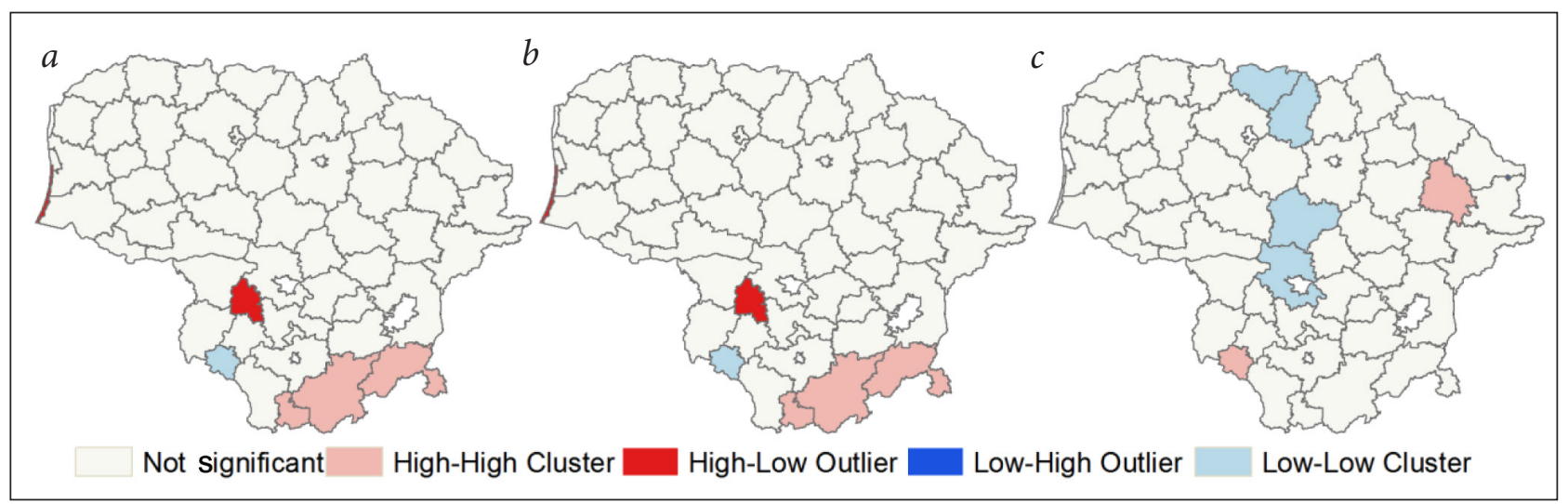

Fig. 2. Spatial clusters and outliers of forest cover properties in Lithuanian municipalities: a - forest cover proportion in $1950, \mathrm{~b}$ - forest cover proportion in 2013, c - increase of forest cover proportion during the period 1950-2013 


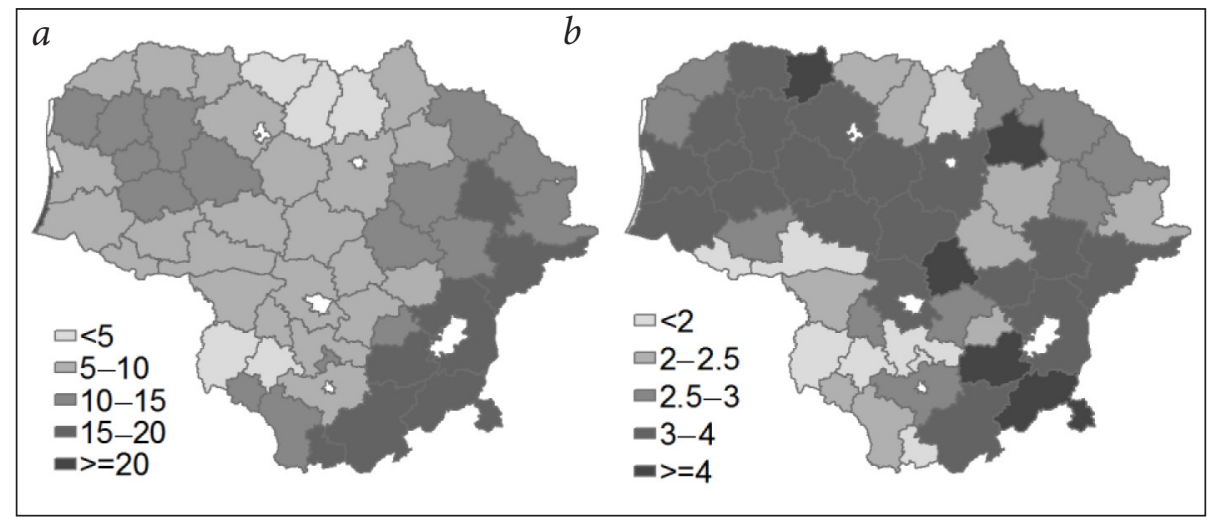

Fig. 3. The percentage of new and lost forest in Lithuanian municipalities in the period 1950-2013: a - new forest, b - deforestation

conditions for agriculture seem to be negatively associated with the appearance of new forest, while the municipalities with worse conditions for agriculture exhibited stronger afforestation trends. A statistically significant global spatial autocorrelation was observed for both the area percentage of new and lost forest - respectively, $I=0.2574$, $Z=3.578, p=0.0003$ and $I=0.206, Z=2.706$, $p=0.007$. The area percentage indicates the share of new/lost forest compared to the whole area of municipality.

A cluster of municipalities with the relatively largest areas of new forests was identified in the south-eastern part of Lithuania (Fig. 4a), however, the Šalčininkai municipality simultaneously was found to be associated with relatively large amounts of deforestation, too (Fig. 4b). Deforestation was relatively slowest around less forested mu- nicipalities (Vilkaviškis and Marijampolè), while the afforestation was relatively slowest around the agricultural Pakruojis municipality.

Most often the forest cover was converted into agricultural land $-61.7 \%$ of deforested areas (Fig. 5). 24.8\% of lost forest is currently identified as scrubland, $7.2 \%$ of the forest cover was inundated, $4.5 \%$ was built-up, $1.41 \%$ converted into roads and $0.27 \%$ became orchards.

The main finding of our study is that we estimated the proportion of the forest cover in 1950 to be $26.5 \%$, and differing from the figure available in all official statistics - $19.7 \%$ (Lietuvos miškų..., 2012a). The last figure is based on the information from stand-wise forest inventories, and we believe that a lot of small forests, formerly owned by farmers, have never been inventoried nor accounted to be included in forest cover statistics.

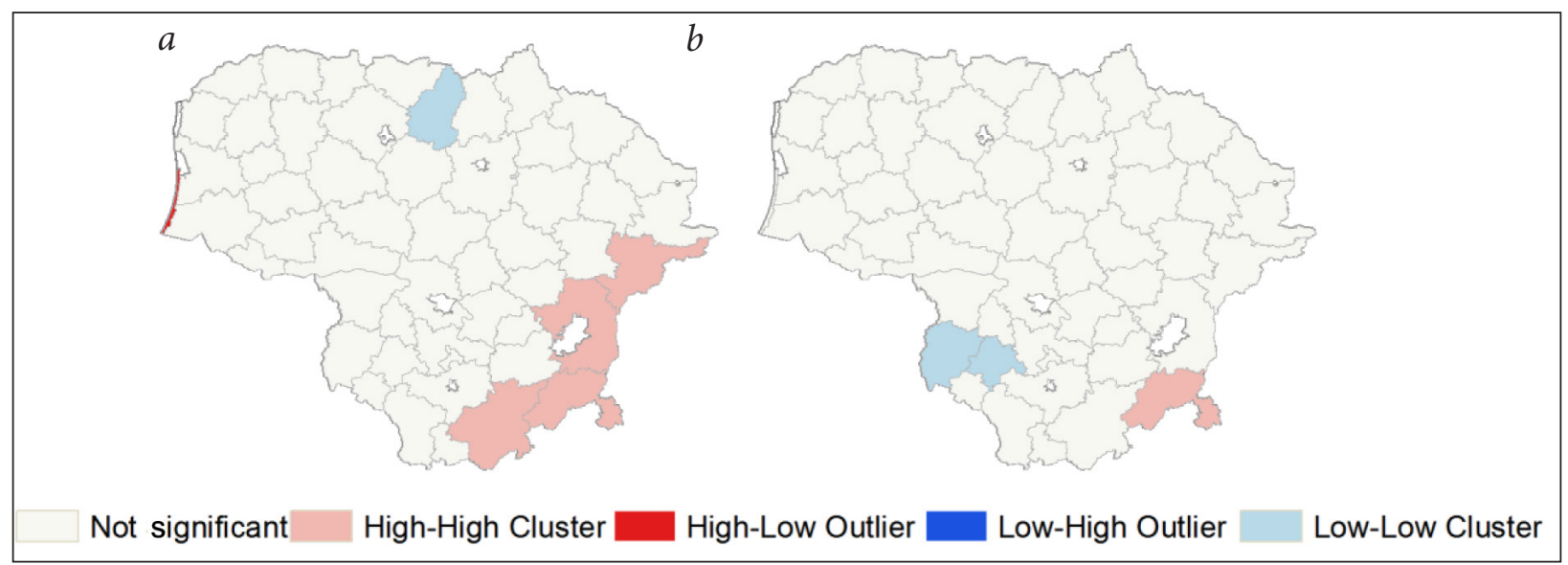

Fig. 4. Spatial clusters and outliers of new/lost forest covers in Lithuanian municipalities: a - new forest, b - deforestation 


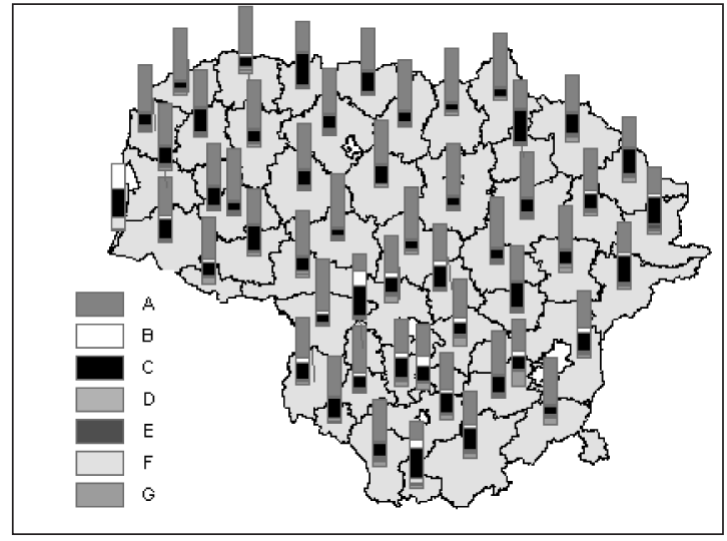

Fig. 5. Current land cover types of deforested areas: A - agricultural land; B - built-up areas; C scrubland; D - meadows; E - orchards, F - roads; $\mathrm{G}$ - waters

Even the afforestation seems to be the prevailing trend shaping the forest cover changes in Lithuania, a significant part of forest has been converted into other land cover types. More in-depth analysis of factors beyond the forest cover dynamics is left outside of the current publication.

\section{CONCLUSIONS}

1. The proportion of the forest cover in Lithuania increased from $26.5 \%$ in 1950 s by $21 \%$ to reach 2195 thousand ha nowadays. The forest cover proportion in 1950s found in the current study exceeds the official statistics ( 19.7\%).

2. The proportion of the forest cover area increased in all municipalities during the period 1950-2013. The largest increase in the forest cover proportion was in the areas less suitable for agriculture, especially in hilly landscapes of Žemaitija and Aukštaitija.

3. The fastest rate of the forest cover proportion increase was concentrated around Kalvarija and Utena municipalities, while the relatively slowest increase of the forest cover proportion was around Joniškis, Pakruojis, Kèdainiai and Kaunas municipalities.

4. The relatively largest areas of new forests were identified in the south-eastern part of Lithuania, with the Šalcininkai municipality simultaneously being associated with relatively large amounts of deforestation. Deforestation was relatively slowest around less forested municipalities (Vilkaviškis and Marijampole), while the afforestation was rel- atively slowest around the agricultural Pakruojis municipality.

5. Deforestation was most commonly associated with the forest transformation into agricultural land, less often into scrublands or waters.

Received 7 September 2015 Accepted 7 December 2015

\section{REFERENCES}

1. Anselin L. 1995. Local indicators of Spatial Association-LISA. Geographical Analysis. Vol. 27(2). P. 93-115.

2. Brukas A. 1987. Tiesos ir melo santykis statistikoje. Girios. Nr. 10, 11.

3. Getis A., Ord J. K. 2010. The Analysis of Spatial Association by use of Distance Statistics. Geographical Analysis. Vol. 24. Issue 3. P. 189-206.

4. Kasperavičius A., Kuliešis A., Mozgeris G. 2000. Satellite imagery based forest resource information and its application for designing the national forest inventory in Lithuania. Proceedings of Conference on Remote Sensing and Forest Monitoring. Poland: Warsaw Agricultural University, Faculty of Forestry Rogow. P. 50-58.

5. Kenstavičius J., Brukas A. 2003. Lietuvos miškingumas, miškų plotai ir jų išsidèstymas. Lietuvos mišku metraštis, XX amžius. Vilnius: Aplinkos ministerija. P. 110-120.

6. Kučas A., Trakimas G., Balčiauskas L., Vaitkus G. 2011. Multi-scale analysis of forest fragmentation in Lithuania. Baltic Forestry. Vol. 17(1). P. 128-135.

7. Lazdinis M., Roberge J. M., Mozgeris G., Angelstam P. 2005. Afforestation planning and biodiversity conservation: Predicting effects on habitat functionalityin Lithuania. Journal of Environmental Planning and Management. Vol. 48(3). P. 331-348.

8. Lietuvos mišku ūkio statistika 2012. Vilnius: Valstybinè miškų tarnyba.

9. Lietuvos mišku ūkio statistika 2013. Kaunas: Lututè.

10. Lietuvos privačiu miško valdu analizè 2014 [žiūrèta 201410 13]. Prieiga per internetą: http://www. amvmt.lt/Images/Veikla/Stat/Privaciu_misku_ statistika/2014_01_01/Lietuvos\%20privaciu\%20 misko\%20valdu\%20anali.pdf

11. Longley P. A., Goodchild M. F., Maguire D. J., Rhind D. W. (eds.). 2005. Geographical Information Systems: Principles, Techniques, Management, and Applications. 2nd Edition, Abridged. John Wiley \& Sons, Inc. $404 \mathrm{p}$.

12. Longley P. A., Goodchild M. F., Maguire D. J., Rhind D. W. 2005. Geographic Information Systems and Science. 2nd Edition. John Wiley \& Sons, Inc. $517 \mathrm{p}$.

13. Matulionis P. 1930. Lietuvos žemé ir jos gyventoju gausumas istorijos būvyje. Kultūra. Nr. 5. P. 241-245. 
14. Ministry of Environment. 2013. Sociological Survey of Lithuanian Citizens on Most Relevant Forestry Issues and Analysis of Respondent's Opinions: Report. Vilnius: JSC Eurosprendimai.

15. Miško žemès plotu kaitos Lietuvoje 1990-2011 m. ivertinimas: atsiskaitomųjų dokumentų rinkinys. Akademija, Kauno r.: Lietuvos nepriklausomų medienos matuotojų asociacija. $100 \mathrm{p}$.

16. Mitchell A. 2005. The ESRI Guide to GIS Analysis. Volume 2. Spatial Measurements and Statistics. ESRI Press. 238 p.

17. Mizaraite D., Mizaras S., Sadauskienè L. 2010. Lithuanian private forestry: situation, tendencies and problems. Baltic Forestry. No. 16. P. 296-302.

18. Pauliukevičius G., Kenstavičius J. 1995. Ekologiniai mišku išdèstymo pagrindai. Vilnius: Geografijos institutas. $289 \mathrm{p}$.
Daiva Juknelienè, Gintautas Mozgeris

\section{MIŠKO DANGOS KAITOS ERDVINIS MARGINYS LIETUVOJE XX A. II PUSĖJE}

\section{Santrauka}

Straipsnyje pristatomos miškų dangos pokyčių tendencijos Lietuvos savivaldybėse. Atliekant tyrimus buvo remtasi dviem informacijos šaltiniais apie miškų dangą $1950 \mathrm{~m}$. ir 2013 m.: (i) geografine miškų dangos baze, sukurta naudojant istorinius ortofotoplanus, paremtus aerofotografavimu, atliktu ką tik pasibaigus Antrajam pasauliniam karui ir (ii) informacija, gauta iš Valstybinio miškų kadastro, su nuoroda ị 2013 metus. Abu sluoksniai palyginti naudojant GIS perdangos metodus.

Duomenys buvo analizuojami agregavus juos iki savivaldybių lygio. Globali Moran’s I ir Anselin vietinè Moran’s I statistikos naudotos nustatant atitinkamai globalius ir vietinius miško dangos marginio pasiskirstymo ypatumus Lietuvos savivaldybėse. Pagrindine šio tyrimo išvada, kad šalies miškingumas 1950 m. siekè 26,5\%, t. y. jis skiriasi nuo oficialiosios statistikos, kurioje nurodoma 19,7 \%. Miškingumas padidejo visose savivaldybėse 1950-2013 metais. Labiausiai tuose regionuose, kurie mažiausia tiko žemès ūkio veiklai. Santykinai didžiausi naujų miškų plotai buvo nustatyti Pietryčių Lietuvoje, lèčiausiai miškų dangos nyko mažai miškų turinčiose savivaldybėse, o apželdinimas mišku vangiausias buvo žemès ūkio veiklai tinkančioje Pakruojo savivaldybejje. Miškų dangos praradimas paprastai siejamas su miško transformacija i žemés ūkio paskirties žemes, rečiau ị krūmynus ar vandens telkinius.

Raktažodžiai: miško dangos pokyčiai, miškingumas, apželdinimas mišku, miškų dangos praradimas, erdvinè statistika, Moran's I 